\title{
Production of Endoglucanases by Streptomyces thermocoprophilus CP1 using Rice Straw as a Substrate
}

\author{
Suriya Tingthong $(\mathbb{D}$, Pitchayaporn Suwanakood $(\mathbb{D}$, \\ Pongsak Rattanachaikunsopon (D) and Jidapa Sangswan* (D)
}

Department of Biological Science, Faculty of Science, Ubon Ratchathani University, Ubon Ratchathani - 34190, Thailand.

\begin{abstract}
Rice straw is a major agricultural waste that can be used as an alternative substrate to expensive raw materials for endoglucanases (CMCase) production by microorganisms. This study aimed to search for a microorganism having the potential to produce endoglucanase from rice straw. From compost samples, 40 bacterial colonies were isolated on carboxymethylcellulose (CMC) agar. Among them, 16 isolates showed a hydrolysis zone on a CMC agar plate with hydrolysis (HC) values ranging from $1.15 \pm 0.02$ to 4.40 \pm 0.52 . Based on hydrolysis zone diameter and HC value, isolates CP1, CP2 and CP3 were further examined for their CMCase production in CMC broth. According to CMCase production and stability, isolate CP1 was selected for further study. The optimal $\mathrm{pH}$ and temperature for $\mathrm{CMCase}$ production of isolate CP1 were 5 and $45^{\circ} \mathrm{C}$, respectively. When using pre-treated rice straw as a substrate for semisolid-state fermentation, the highest CMCase activity of $0.142 \pm 0.008 \mathrm{U} / \mathrm{mL}$ was obtained in a medium containing pre-treated rice straw of $60 \mathrm{~g} / \mathrm{L}$. The sequence alignment analysis and phylogenetic analysis suggested that the isolate CP1 was likely to be Streptomyces thermocoprophilus. The microorganism obtained from this study may be not only industrially important but also beneficial to the environment.

Keywords: Endoglucanases, Streptomyces thermocoprophilus, rice straw, actinomyces, semi-solid-state fermentation
\end{abstract}

*Correspondence: sanom.n@ubu.ac.th; +66-45-288380

(Received: June 26, 2021; accepted: September 13, 2021)

Citation: Tingthong S, Suwanakood P, Rattanachaikunsopon P, Sangswan J. Production of Endoglucanases by Streptomyces thermocoprophilus CP1 using Rice Straw as a Substrate. J Pure App/ Microbiol. 2021;15(4):1963-1975. doi: 10.22207/JPAM.15.4.18

(C) The Author(s) 2021. Open Access. This article is distributed under the terms of the Creative Commons Attribution 4.0 International License which permits unrestricted use, sharing, distribution, and reproduction in any medium, provided you give appropriate credit to the original author(s) and the source, provide a link to the Creative Commons license, and indicate if changes were made. 


\section{INTRODUCTION}

Cellulase enzymes are a group of complex enzymes converting cellulose to glucose and other sugars. The cellulase enzymes comprise three major types of enzymes: endoglucanases (E.C. 3.2.1.4), exoglucanases, including cellobiohydrolases (CBHs) (E.C. 3.2.1.91) and $\beta$-glucosidase (E.C. 3.2.1.21). ${ }^{1-3}$ Endoglucanases randomly breakdown $\beta-1,4$ glycosidic bonds in the cellulose strand releasing glucose and oligosaccharides. Cellobiohydrolases act at termini of cellulose and oligosaccharides produced by endoglucanases to convert them to cellobiose which is further digested by $\beta$-glucosidase to glucose. ${ }^{4}$ Synergetic activities of all these three enzymes provide the best result of complete hydrolysis of raw cellulose to glucose. ${ }^{5}$

Cellulases are important enzymes with many applications in many industries and agriculture, especially in bioethanol production, ${ }^{6}$ textile and food industries. ${ }^{7}$ Although the enzymes are found to be produced by fungi and bacteria, ${ }^{8}$ those from bacteria including actinomyces are become exploited because of their high growth rate and availability in diverse habitats, including extreme environments that are sources of thermophilic, psychrophilic, alkaliphilic, acidophilic, and halophilic strains. ${ }^{9}$ Actinomycetes become an attractive microorganism for cellulase production. Various strains of actinomyces have been evaluated for their ability to degrade the lignocellulosic biomass, which can be potentially implemented in the lignocellulolytic enzymes production from different value-added products. ${ }^{10}$ Lignocellulosic biomass (LCB) is the most abundant organic compound found in nature, especially in plant cell walls. ${ }^{11}$ Recently, LCB has gained increasing attention as economic feedstock for second-generation (2G) biofuels. ${ }^{12}$ LCB conversion to bioethanol consists of four major steps including pretreatment, saccharification, fermentation and distillation. ${ }^{13}$ The pretreatment process is performed to remove or redistribute the lignin, to reduce the cellulose crystallinity, and to increase the porosity significantly. ${ }^{14}$ Subsequent saccharification or hydrolysis is done by acids or enzymes to hydrolyze cellulose and hemicellulose into fermentable sugars (hexoses and pentoses). Enzymatic hydrolysis is preferred over acid hydrolysis due to low energy requirement and by-product formation. The enzymes required for efficient deconstruction of polysaccharides into monomeric sugars include modular and nonmodular glycosyl hydrolases (GHs) comprising of cellulases and hemicellulases, carbohydrate esterases (CEs), and auxiliary activity (AA) proteins. ${ }^{15}$

Rice straw is a major agricultural biomass waste produced in Southeast Asia and particularly in Thailand, and yet most of this biomass is left unutilized and is often burned in the field causing severe environmental problems at both local and global levels. It is estimated that over 20 million ton of rice straw are produced in Thailand every year. ${ }^{16}$ Similar to other plant residues, rice straw is mainly composed of cellulose, hemicellulose, and lignin. ${ }^{17}$ Cellulose is a complex carbohydrate with a high molecular weight and a maximum of 10,000 monomeric units of D-glucose, linked by $\beta-1,4-$ glycosidic bonds. Hemicellulose is strongly linked to the surface of cellulose microfibrils. It entirely consists of pentose (xylose and arabinose) and hexose sugars (glucose, galactose, mannose, and rhamnose). Lignin denotes a complex amorphous aromatic polymer with a three-dimensional network, composed of phenylpropane units linked together. ${ }^{18}$ Having a complex structure consisting mainly of cellulose and hemicellulose, rice straw is difficult to be degraded and utilized as a bio-resource. ${ }^{19}$ To overcome such problem, the invention of efficient, practical and cost effective approaches to rice straw degradation is necessary. The attractive of using lignocellulosic biomass as a sustainable feedstock for biofuel and others valuable bioactive compound productions, many research works related to isolating cellulase producing actinomyces and their applications were conducted during the last five years as summarized in Table 1. In the present study, various actinomyces were isolated from compost made in Ubon Ratchathani, Thailand and screened for their potential to produce cellulolytic enzymes. The actinomyces with the most efficient cellulase production was further evaluated for its ability to produces cellulase when using rice straw as a substrate. The production of cellulase enzymes from biomass is a way to increase the value of agricultural waste and reduce raw material cost of enzyme production process. 
Table 1. Research works related to isolating cellulase producing actinomyces and their applications during the last five years

\begin{tabular}{|c|c|c|c|c|c|c|}
\hline $\begin{array}{l}\text { Source of } \\
\text { actinomyces }\end{array}$ & $\begin{array}{l}\text { Pre- } \\
\text { treatment } \\
\text { method }\end{array}$ & $\begin{array}{l}\text { Enzymes } \\
\text { production } \\
\text { conditions }\end{array}$ & $\begin{array}{l}\text { Maximum } \\
\text { enzyme } \\
\text { activity }\end{array}$ & Selected strains & $\begin{array}{l}\text { Future } \\
\text { application }\end{array}$ & Ref. \\
\hline soil & $\begin{array}{l}\text { without } \\
\text { pretreatment }\end{array}$ & $\begin{array}{l}0.5 \% \mathrm{CMC} \\
\mathrm{pH} 6.5 \\
\text { Temp } 45^{\circ} \mathrm{C} \\
160 \mathrm{rpm}, 4 \mathrm{~d}\end{array}$ & $\begin{array}{l}\text { endoglucanase } \\
27 \mathrm{IU} / \mathrm{mL}\end{array}$ & $\begin{array}{l}\text { Streptomyces sp. } \\
\text { DSK59 }\end{array}$ & $\begin{array}{l}\text { sorghum } \\
\text { stover } \\
\text { hydrolysis } \\
\text { incombinaion } \\
\text { with } \\
\text { commercial } \\
\text { cellulase }\end{array}$ & 20 \\
\hline $\begin{array}{l}\text { soil of an } \\
\text { olive } \\
\text { pressing } \\
\text { factory }\end{array}$ & $\begin{array}{l}\text { mashing }(\varnothing<1 \\
\mathrm{mm})\end{array}$ & $\begin{array}{l}3 \% \text { olive } \\
\text { pomace powder } \\
\text { pH } 7.4 \\
\text { Temp } 40^{\circ} \mathrm{C} \\
150 \mathrm{rpm}, 30 \mathrm{~d}\end{array}$ & $\begin{array}{l}\text { cellulase } \\
1.44 \pm 0.02 \\
\mathrm{U} / \mathrm{mL}\end{array}$ & $\begin{array}{l}\text { Streptomyces sp. } \\
\text { S1M3I }\end{array}$ & animal feed & 21 \\
\hline $\begin{array}{l}\text { agricultural } \\
\text { and agro- } \\
\text { industrial } \\
\text { residues/ }\end{array}$ & $\begin{array}{l}\text { grinding to an } \\
\text { average size of } \\
0.5 \mathrm{~mm}\end{array}$ & $\begin{array}{l}10 \% \text { of } \\
\text { decomposed } \\
\text { rubber bark } \\
\text { without } \mathrm{pH} \\
\text { adjustment } \\
\text { Temp } 30^{\circ} \mathrm{C} \\
150 \mathrm{rpm}, 4 \mathrm{~d} \\
10 \% \text { of } \\
\text { decomposed } \\
\text { rubber bark } \\
\text { without } \mathrm{pH} \\
\text { adjustment } \\
\text { Temp } 45^{\circ} \mathrm{C} \\
150 \mathrm{rpm}, 4 \mathrm{~d}\end{array}$ & $\begin{array}{l}\text { CMCase } \\
0.52 \mathrm{U} / \mathrm{mL} \\
\text { xylanase } \\
0.46 \mathrm{U} / \mathrm{mL}\end{array}$ & $\begin{array}{l}\text { S. } \\
\text { thermocarboxydus } \\
\text { A21 }\end{array}$ & $\begin{array}{l}\text { use in } \\
\text { composting } \\
\text { process of } \\
\text { rubber bark }\end{array}$ & 22 \\
\hline soil & $\begin{array}{l}\text { without } \\
\text { pretreatment }\end{array}$ & $\begin{array}{l}1 \% \mathrm{CMC} \\
\text { without } \mathrm{pH} \\
\text { adjustment } \\
\text { Temp } 37^{\circ} \mathrm{C} \\
120 \mathrm{rpm} \\
5 \mathrm{~d} \\
1 \% \mathrm{CMC} \\
\text { without pH } \\
\text { adjustment } \\
\text { Temp } 37^{\circ} \mathrm{C} \\
120 \mathrm{rpm}, 5 \mathrm{~d}\end{array}$ & $\begin{array}{l}\text { endoglucanase } \\
4.0 \mathrm{U} / \mathrm{mL}\end{array}$ & $\begin{array}{l}\text { S. macrosporeus } \\
\text { BB } 32\end{array}$ & $\begin{array}{l}\text { endoglucanase } \\
\text { production }\end{array}$ & 23 \\
\hline $\begin{array}{l}\text { lignocellulosic } \\
\text { compost }\end{array}$ & $\begin{array}{l}\text { grinding/ } \\
\text { soaking in } \\
15 \%(\mathrm{w} / \mathrm{v}) \\
\mathrm{NaOH} \text { with } \\
3 \% \mathrm{H}_{2} \mathrm{O}_{2} \\
\text { for } 4 \mathrm{~h} \text { and } \\
\text { autoclaved at } \\
121^{\circ} \mathrm{C}, 5 \mathrm{~min}\end{array}$ & $\begin{array}{l}2 \% \text { of empty } \\
\text { fruit bunch } \\
\mathrm{pH} 6.5 \\
\text { Temp } 45^{\circ} \mathrm{C} \\
150 \mathrm{rpm}, 5 \mathrm{~d}\end{array}$ & $\begin{array}{l}\text { endoglucanase } \\
925 \mathrm{U} / \mathrm{g} \\
\text { substrate }\end{array}$ & $\begin{array}{l}\text { S. } \\
\text { thermocoprophilus } \\
\text { TC13W }\end{array}$ & $\begin{array}{l}\text { endoglucanase } \\
\text { production from } \\
\text { low cost } \\
\text { agriculture } \\
\text { waste }\end{array}$ & 24 \\
\hline
\end{tabular}


Table 1. Cont....

\begin{tabular}{|c|c|c|c|c|c|c|}
\hline $\begin{array}{l}\text { Source of } \\
\text { actinomyces }\end{array}$ & $\begin{array}{l}\text { Pre- } \\
\text { treatment } \\
\text { method }\end{array}$ & $\begin{array}{l}\text { Enzymes } \\
\text { production } \\
\text { conditions }\end{array}$ & $\begin{array}{l}\text { Maximum } \\
\text { enzyme } \\
\text { activity }\end{array}$ & Selected strains & $\begin{array}{l}\text { Future } \\
\text { application }\end{array}$ & Ref. \\
\hline $\begin{array}{l}\text { soil, rotten } \\
\text { wood, leaf } \\
\text { and } \\
\text { rice straw }\end{array}$ & $\begin{array}{l}\text { soaking rice } \\
\text { straw in } 1 \% \\
(\mathrm{w} / \mathrm{v}) \mathrm{NaOH} \\
\text { for } 24 \mathrm{~h} \\
\text { soaking } \\
\text { sugarcane } \\
\text { bagasse in } 1 \% \\
(\mathrm{w} / \mathrm{v}) \mathrm{NaOH} \\
\text { for } 24 \mathrm{~h} \\
\text { mashing }(800 \\
\text { and } 2000 \mu \mathrm{m})\end{array}$ & $\begin{array}{l}1 \% \text { rice straw } \\
\mathrm{pH} 7.0 \\
\text { Temp } 30^{\circ} \mathrm{C} \\
100 \mathrm{rpm}, 12 \mathrm{~d} \\
1 \% \text { sugarcane } \\
\text { bagasse } \\
\mathrm{pH} 7.0 \\
\text { Temp } 30^{\circ} \mathrm{C} \\
100 \mathrm{rpm}, 12 \mathrm{~d} \\
\text { rye bran } \\
\text { solid state } \\
\text { fermentation } \\
\text { without } \mathrm{pH} \\
\text { adjustment } \\
30^{\circ} \mathrm{C}, 6 \mathrm{~d}\end{array}$ & $\begin{array}{l}\text { endoglucanase } \\
13.85 \pm 0.22 \mathrm{U} / \mathrm{g} \\
\text { amylase } \\
20.97 \pm 0.16 \mathrm{U} / \mathrm{g} \\
\text { pectinase } \\
11.24 \pm 0.14 \mathrm{U} / \mathrm{g} \\
\text { xylanase } \\
15.22 \pm 0.11 \mathrm{U} / \mathrm{g} \\
\text { endoglucanase } \\
0.142 \pm 0.008 \\
\mathrm{U} / \mathrm{mL}\end{array}$ & $\begin{array}{l}\text { S. } \\
\text { thermocoprophilus } \\
\text { CP1 }\end{array}$ & $\begin{array}{l}\text { use in ethanol } \\
\text { or bioactive } \\
\text { natural products } \\
\text { production } \\
\text { from } \\
\text { lignocellulosic } \\
\text { biomass }\end{array}$ & $\begin{array}{l}\text { This } \\
\text { study }\end{array}$ \\
\hline
\end{tabular}

\section{MATERIALS AND METHODS}

Isolation of endoglucanases-producing actinomyces from compost

The samples of composting agricultural waste were collected from the Faculty of Agriculture, Ubon Ratchathani University, Thailand. One gram of compost sample was subjected to ten-fold serial dilution with sterilized peptone water containing peptone $1.0, \mathrm{NaCl} 8.5$ (g/L). One $\mathrm{mL}$ of each dilution (for $10^{-4}$ to $10^{-6}$ ) was spread on carboxymethylcellulose (CMC) agar and then incubated at $37^{\circ} \mathrm{C}$ until colonies were observed. Colonies with different morphological characteristics were picked up. The selected colonies were purified by cross streak technique on $\mathrm{CMC}$ agar and stored at $4^{\circ} \mathrm{C}$ in CMC slant and $20 \%$ $(\mathrm{v} / \mathrm{v})$ glycerol at $-20^{\circ} \mathrm{C}$. All of them were subjected to gram staining and cell morphology investigation under a light microscope.

The rice straw pretreatment

Rice straw locally grown in Warin Chamrap district, Ubon Ratchathani province, Thailand was collected, washed, cut, dried at $60^{\circ} \mathrm{C}$ and crushed to $0.5 \mathrm{~mm}$ particles. The resulting particles were treated with $2 \%(\mathrm{w} / \mathrm{v}) \mathrm{NaOH}$ at room temperature for $24 \mathrm{~h}$ and washed with water till neutral $\mathrm{pH}$ and dried at $60^{\circ} \mathrm{C}$.

Primary screening for endoglucanases-producing actinomyces

The primary screening of endoglucanasesproducing actinomyces was carried out on an agar medium (CMC plate assay method). All of the isolated actinomyces cells were pre-cultured on $\mathrm{CMC}$ broth at $37^{\circ} \mathrm{C}$ for $3 \mathrm{~d}$. After that $5 \mu \mathrm{L}$ of cultures were dropped on CMC agar and then incubated at $37^{\circ} \mathrm{C}$. After $7 \mathrm{~d}$ incubation, a lugoliodine solution was poured over CMC plates for $15 \mathrm{~min}$ and then rinsed off. A clear zone formation around the actinomyces colonies indicated the hydrolysis of CMC. The highest endoglucanases activity is assumed by the highest ratio of the clear zone diameter to colony diameter. Hydrolysis capacity $(\mathrm{HC})$ value was calculated as described by Lu et al. ${ }^{27}$ 
Table 2. The colony and cell morphology and Gram's stain of 16 isolated actinomyces

\begin{tabular}{lcll}
\hline Isolate & Colony morphology & Cell morphology & Gram's stain \\
\hline CP1 & round lobate and convex & filamentous & positive \\
CP2 & Irregular lobate and convex & filamentous & positive \\
CP3 & Irregular lobate and convex & filamentous & positive \\
CP4 & Irregular lobate and convex & filamentous & positive \\
CP5 & Irregular lobate and convex & filamentous & positive \\
CP7 & round lobate and convex & filamentous & positive \\
CP8 & Irregular lobate and convex & filamentous & positive \\
CP9 & Irregular lobate and convex & filamentous & positive \\
CP17 & round lobate and convex & filamentous & positive \\
CP18 & Irregular lobate and convex & filamentous & positive \\
CP28 & Irregular lobate and convex & filamentous & positive \\
CP29 & Irregular lobate and convex & filamentous & positive \\
CP31 & Irregular lobate and convex & filamentous & positive \\
CP38 & round lobate and convex & filamentous & positive \\
CP39 & Irregular lobate and convex & filamentous & positive \\
CP40 & Irregular lobate and convex & filamentous & positive \\
\hline
\end{tabular}

Secondary screening for endoglucanasesproducing actinomyces

Three isolates with high $\mathrm{HC}$ values or large clear zones were evaluated for their endoglucanases production potential in CMC broth. The actinomyces cells were activated on CMC agar at $37^{\circ} \mathrm{C}$ until sporulation. The spore suspension was prepared by scratching of each agar with $10 \mathrm{~mL}$ distilled water containing $0.1 \%$ tween 80 . For endoglucanases production, $2 \mathrm{~mL}$ of the spore suspension was used to inoculate into a flask containing $50 \mathrm{~mL} \mathrm{CMC}$ broth and then incubated at $37^{\circ} \mathrm{C}$ for $10 \mathrm{~d}$. Samples were taken every $2 \mathrm{~d}$ for cellulase activity assay. The samples were centrifuged at 5,000 rpm for $20 \mathrm{~min}$ and the resulting supernatants were used for enzyme activity assay.

Effect of pH and temperatures on endoglucanases production

The optimal $\mathrm{pH}$ and temperature for endoglucanases production of the selected isolate CP1 were determined. To determine the optimal $\mathrm{pH}$, the isolate $\mathrm{CP} 1$ was pre-cultured on $\mathrm{CMC}$ broth at $37^{\circ} \mathrm{C}$ for $3 \mathrm{~d}$. After that $5 \mu \mathrm{L}$ of cultures were dropped on $\mathrm{CMC}$ agar with different $\mathrm{pH}$ ranging from 3 to 8 and incubated at $37^{\circ} \mathrm{C}$ for $5 \mathrm{~d}$. To determine the optimal temperature, five plates of $\mathrm{CMC}$ agar with $\mathrm{pH}$ adjusted to 5 were inoculated and incubated at different temperatures including $30,35,40,45$, and $50^{\circ} \mathrm{C}$ for $5 \mathrm{~d}$. After incubation, a clear zone diameter was determined and $\mathrm{HC}$ values were calculated.

Endoglucanases production by using pretreated rice straw

To evaluate the ability of isolate CP1 to produce endoglucanases when using rice straw as a substrate, semi-solid-state fermentation was performed. Two $\mathrm{mL}$ of the spore suspension with the initial spore concentration of 107 spores $/ \mathrm{mL}$ was used as an inoculum. Fermentation medium containing $1 \mathrm{~g}$ of pretreated rice straw moistened with $15 \mathrm{~mL}$ mineral solution containing $\mathrm{CaCl}_{2}$ $0.1, \mathrm{MgSO}_{4} .7 \mathrm{H}_{2} \mathrm{O} 0.1, \mathrm{~K}_{2} \mathrm{HPO}_{4} 1.0, \mathrm{NaCl} 0.2$, yeast extract 5.0, tween $801.5,\left(\mathrm{NH}_{4}\right)_{2} \mathrm{SO}_{4} 0.5, \mathrm{FeSO}_{4}$ 0.1 and $\mathrm{NaNO}_{3} 1.0$ (g/L) in $250 \mathrm{ml}$ Erlenmeyer and culture condition at $37^{\circ} \mathrm{C}$ for $5 \mathrm{~d}$ were used. At the end of the fermentation process, the supernatant obtained from centrifugation at $5000 \mathrm{rpm}$ for 20 min was used for endoglucanases activity assay. CMCase activity assay

CMCase or endoglucanase activity was assayed followed the method of Ghose ${ }^{28}$ with slightly modification. The reaction mixture of substrate $(\mathrm{pH} \mathrm{4.8)}$ and crude enzyme was incubated at $50^{\circ} \mathrm{C}$ for $10 \mathrm{~min}$. The reducing sugar was analyzed by the method described by Miller. ${ }^{29}$ One enzyme unit $(U)$ is defined as the amount of enzyme required to produce $1 \mu$ moles of glucose per min under the assay conditions. CMCase activity was expressed as units per $\mathrm{mL}$ of a crude enzyme $(\mathrm{U} / \mathrm{mL})$. 
Tingthong et al. | J Pure Appl Microbiol | 15(4):1963-1975 | December 2021 | https://doi.org/10.22207/JPAM.15.4.18

Table 3. Diameter of colony and hydrolysis zone of 16 isolates when grown on $\mathrm{CMC}$ agar for $5 \mathrm{~d}$ at $37^{\circ} \mathrm{C}$

\begin{tabular}{|c|c|c|c|c|c|c|c|c|c|}
\hline \multirow[t]{2}{*}{ Isolate } & \multicolumn{4}{|c|}{ Colony diameter $(\mathrm{cm})$} & \multicolumn{4}{|c|}{ Hydrolysis zone diameter $(\mathrm{cm})$} & \multirow[t]{2}{*}{$\mathrm{HC}$ value } \\
\hline & 1 & 2 & 3 & average & 1 & 2 & 3 & average & \\
\hline CP1 & 2.35 & 2.35 & 2.35 & $2.35 \pm 0.00$ & 5.40 & 5.40 & 5.20 & $5.33 \pm 0.09$ & $2.24 \pm 0.04$ \\
\hline $\mathrm{CP} 2$ & 0.90 & 0.70 & 0.90 & $0.83 \pm 0.12$ & 3.65 & 3.35 & 3.55 & $3.52 \pm 0.12$ & $4.40 \pm 0.52$ \\
\hline CP3 & 0.90 & 0.90 & 1.05 & $0.95 \pm 0.09$ & 3.55 & 3.60 & 3.65 & $3.60 \pm 0.04$ & $3.79 \pm 0.18$ \\
\hline CP5 & 1.20 & 1.10 & 1.35 & $1.22 \pm 0.13$ & 3.90 & 3.80 & 3.95 & $3.88 \pm 0.06$ & $3.24 \pm 0.25$ \\
\hline CP7 & 2.00 & 2.00 & 2.05 & $2.02 \pm 0.03$ & 3.05 & 2.95 & 2.95 & $2.98 \pm 0.05$ & $1.50 \pm 0.03$ \\
\hline CP8 & 1.90 & 1.90 & 1.80 & $1.87 \pm 0.06$ & 2.35 & 2.45 & 2.35 & $2.38 \pm 0.05$ & $1.26 \pm 0.02$ \\
\hline CP9 & 1.00 & 1.00 & 1.20 & $1.07 \pm 0.12$ & 3.55 & 3.50 & 3.80 & $3.62 \pm 0.13$ & $3.42 \pm 0.16$ \\
\hline CP17 & 1.30 & 1.40 & 1.35 & $1.35 \pm 0.05$ & 1.55 & 1.50 & 1.55 & $1.53 \pm 0.02$ & $1.15 \pm 0.02$ \\
\hline CP18 & 2.00 & 1.90 & 2.00 & $1.97 \pm 0.06$ & 2.95 & 2.95 & 2.85 & $2.92 \pm 0.05$ & $1.48 \pm 0.05$ \\
\hline CP25 & 1.50 & 1.60 & 1.45 & $1.52 \pm 0.08$ & 3.10 & 3.05 & 3.10 & $3.08 \pm 0.02$ & $2.05 \pm 0.08$ \\
\hline CP26 & 1.10 & 1.00 & nd & $0.70 \pm 0.07$ & 3.55 & 3.35 & nd & $2.30 \pm 0.10$ & $3.39 \pm 0.08$ \\
\hline CP28 & 1.20 & 1.20 & 0.75 & $1.05 \pm 0.26$ & 3.60 & 3.70 & 3.20 & $3.50 \pm 0.22$ & $3.42 \pm 0.52$ \\
\hline CP29 & 1.70 & 1.90 & 1.80 & $1.80 \pm 0.10$ & 2.35 & 2.45 & 2.35 & $2.38 \pm 0.05$ & $1.31 \pm 0.03$ \\
\hline CP38 & 2.10 & 2.00 & 2.10 & $2.07 \pm 0.06$ & 3.10 & 3.30 & 3.20 & $3.20 \pm 0.08$ & $1.52 \pm 0.01$ \\
\hline CPY & 0.90 & 1.20 & nd & $0.70 \pm 0.21$ & 3.45 & 3.85 & nd & $3.65 \pm 0.20$ & $3.35 \pm 0.48$ \\
\hline $\mathrm{CPZ}$ & 1.30 & 1.30 & 1.20 & $1.27 \pm 0.06$ & 4.15 & 4.05 & 4.05 & $4.08 \pm 0.05$ & $3.25 \pm 0.07$ \\
\hline
\end{tabular}

nd = not determine

\section{Molecular identification of isolate CP1}

Molecular techniques were conducted to identify the isolate CP1. The 16S rRNA gene was amplified from the isolate CP1 genomic DNA by the conventional PCR method using universal primer pairs, 27F and 1492R. The amplicon was sent to Macrogen for sequencing. The sequence was subjected to sequence alignment analysis using NCBI BLASTN program. Multiple alignments by ClustalW and Neighbor Joining tree construction of the CP1 16S rRNA gene and those of other Streptomyces species available on GenBank database were conducted on MEGA 7.0 software.

\section{RESULTS}

From the compost samples, a total of 40 isolates grown on CMC agar were collected. Among them, only 16 isolates produced a zone of hydrolysis indicating the production of extracellular endoglucanases (Table 2). Colony morphological observation showed that all of them had similar characteristics such as cream color, lobate margin, and convex surface except for shape being observed as round or irregular (Table 2). Observation under a light microscope indicated that all of them grew as filamentous and were found to be gram-positive bacteria.

Based on the result of the CMC plate assay method, out of the total 40 isolates, 16 isolates showed zone of hydrolysis indicating production of extracellular endoglucanases. The isolate $\mathrm{CP} 1$ grew on $\mathrm{CMC}$ agar and produced the largest hydrolysis zone (Table 3 ). However, the highest $\mathrm{HC}$ values of $4.40 \pm 0.52,3.79 \pm 0.18$ were observed in isolates CP2 and CP3, respectively (Table 3). Therefore, isolates CP1, CP2 and CP3 were further investigated for their ability to produce endoglucanases enzyme in liquid CMC medium.

To compare endoglucanases production of isolates CP1 CP2 and CP3, CMCase activity profiles were followed every $2 \mathrm{~d}$ until $14 \mathrm{~d}$. In the first $6 \mathrm{~d}$ of observation, CMCase activities of all 3 isolates were somewhat stable. After day 6 , CMCase activities of CP2 and CP3 substantially decrease whereas that of CP1 continuously increased towards the end of fermentation (Fig. 1). Based on CMCase production and stability, isolate CP1 was selected for further investigation.

The optimal $\mathrm{pH}$ and temperature for isolate CP1 to provide the highest endoglucanases activity were determined. To determine the optimal $\mathrm{pH}$, hydrolysis zones produced by isolate $\mathrm{CP} 1$ grown on CMC agar adjusted pH between 4 and 8 were observed. It was revealed that the optimal $\mathrm{pH}$ for endoglucanases production was 
between $\mathrm{pH} 4$ and 5 where the largest hydrolysis zones were observed (Fig. 2). At pH 6 and 7, hydrolysis zones were decreased in size and not observed at $\mathrm{pH} 8$ (Fig. 2). However, the growth of isolate $\mathrm{CP} 1$ at $\mathrm{pH}$ 6-8 was better than at $\mathrm{pH}$ 4-5 indicating that isolate $\mathrm{CP}$ would prefer acidic conditions for endoglucanases production and neutral or weak acidic or alkali conditions for their growth.

The influence of temperature on endoglucanases activity was determined by incubating the $\mathrm{CMC}$ agar plates at a range of temperatures of $30,35,40,45$, and $50^{\circ} \mathrm{C}$. It was observed that $\mathrm{HC}$ values increased with increasing temperature and the optimal temperature for endoglucanases production was $45^{\circ} \mathrm{C}$ (Fig. 3). However, endoglucanases production decreased when temperature was increased up to $50^{\circ} \mathrm{C}$.

To apply rice straw as a substrate for endoglucanases production by isolate CP1, substrate concentration is essential to support the proper growth of the bacteria. Therefore, the effect of rice straw content on endoglucanases production was studied. Different amounts of pre-treated rice straw $(1,2,34$ and $5 \mathrm{~g})$ were moist with $50 \mathrm{~mL}$ of distilled water and spores with the initial concentration of $1 \times 107$ spores/ $\mathrm{mL}$ were inoculated to the rice straw. Although, the optimal temperature for endoglucanases production of isolate $\mathrm{CP} 1$ was $45^{\circ} \mathrm{C}$ but incubating at that temperature caused reduction of water content. Therefore, semi-solid-state fermentation was carried out at $40^{\circ} \mathrm{C}$. When using rice straw contents of 20-60 g/L, a continuous increase of CMCase activity was observed (Fig. 4). However, increasing rice straw contents up to $80-100 \mathrm{~g} / \mathrm{L}$ lowered the CMCase activity (Fig. 4).

The partial sequence of the isolate CP1 16S rRNA gene obtained from PCR amplification was deposited to the GenBank sequence database under the accession number MZ413512. The sequence was subjected to sequence alignment analysis and phylogenetic analysis. The sequence alignment analysis using NCBI BLASTN program

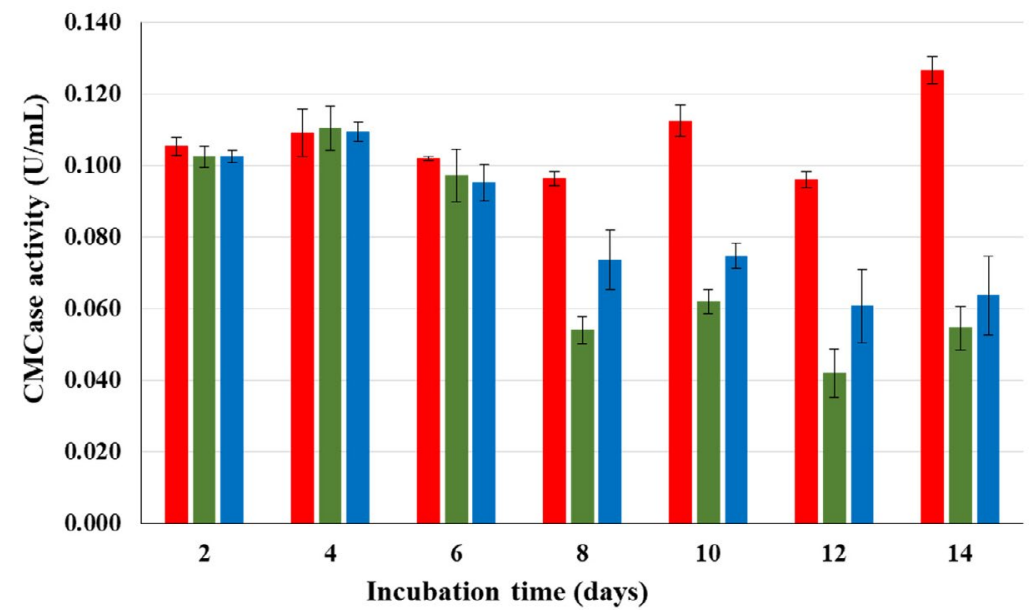

Fig. 1. CMCase activities of isolates CP1$$
\text { CP2 }
$$
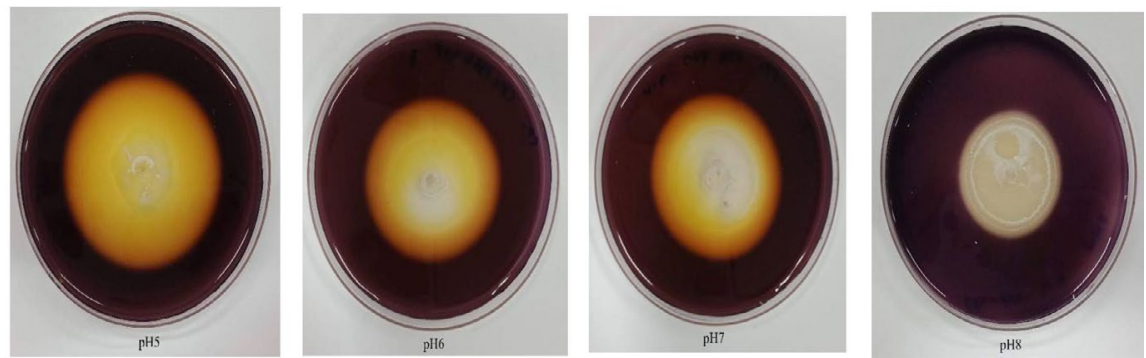

Fig. 2. Effect of $\mathrm{pH}$ on endoglucanases production of isolate $\mathrm{CP} 1$ when grown on $\mathrm{CMC}$ agar and incubated at $37^{\circ} \mathrm{C}$ for $5 \mathrm{~d}$. 
revealed that the sequence of CP1 $16 \mathrm{~S}$ rRNA gene was $99.57 \%$ identical to that of Streptomyces thermocoprophilus strain NBRC 100771 (accession number NR_112594.1). The phylogenetic tree constructed from 16S rRNA genes of the isolate CP1 and other Streptomyces species available on the GenBank database revealed that the isolate CP1 was closely related to Strptomyces thermocoprophilus strain NBRC 100771 with high bootstrap support of $91 \%$ (Fig. 5). The concordance of the results from sequence alignment analysis and phylogenetic analysis suggested that the isolate CP1 was likely to be Streptomyces thermocoprophilus.

\section{DISCUSSION}

An important step for the utilization of lignocellulosic biomass is the conversion of the biomass into smaller and simple structures. This step requires the catalytic activity of lignocellulolytic enzymes including cellulases, hemicellulases, and lignolytic enzyme. ${ }^{10}$ Therefore, attempts have been spent to isolate new microorganisms producing high activity of cellulolytic enzymes. Many different habitats such as soil, compost, ${ }^{30}$ forest waste, ${ }^{31}$ animal feces, ${ }^{32}$ paper mills, and hot springs ${ }^{33}$ have been used as the sources of isolating cellulase producing microorganisms. In the present study, composts

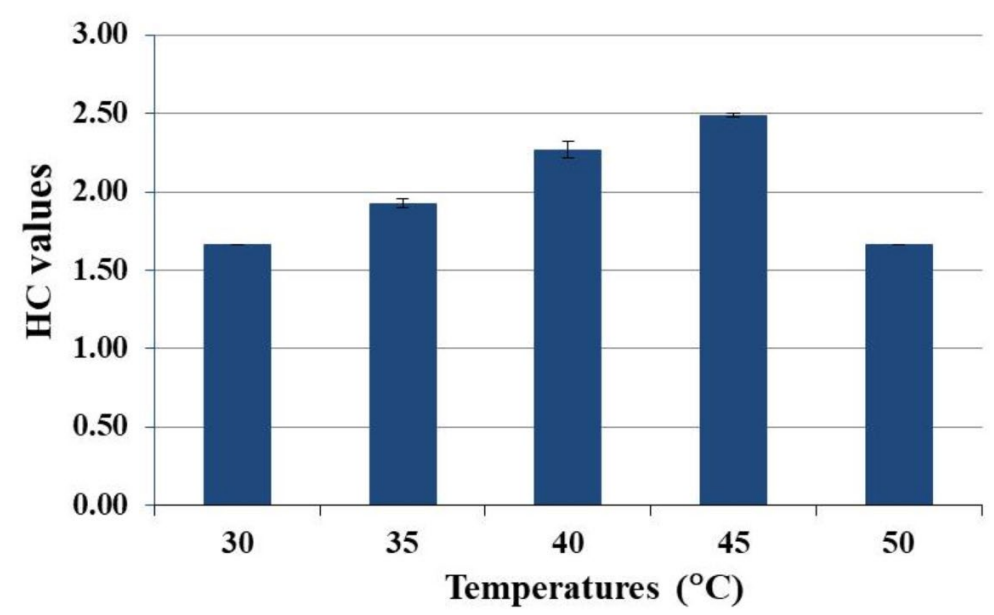

Fig. 3. Effect of temperature on endoglucanases production of $\mathrm{CP} 1$ when grown on $\mathrm{CMC}$ agar for $5 \mathrm{~d}$.

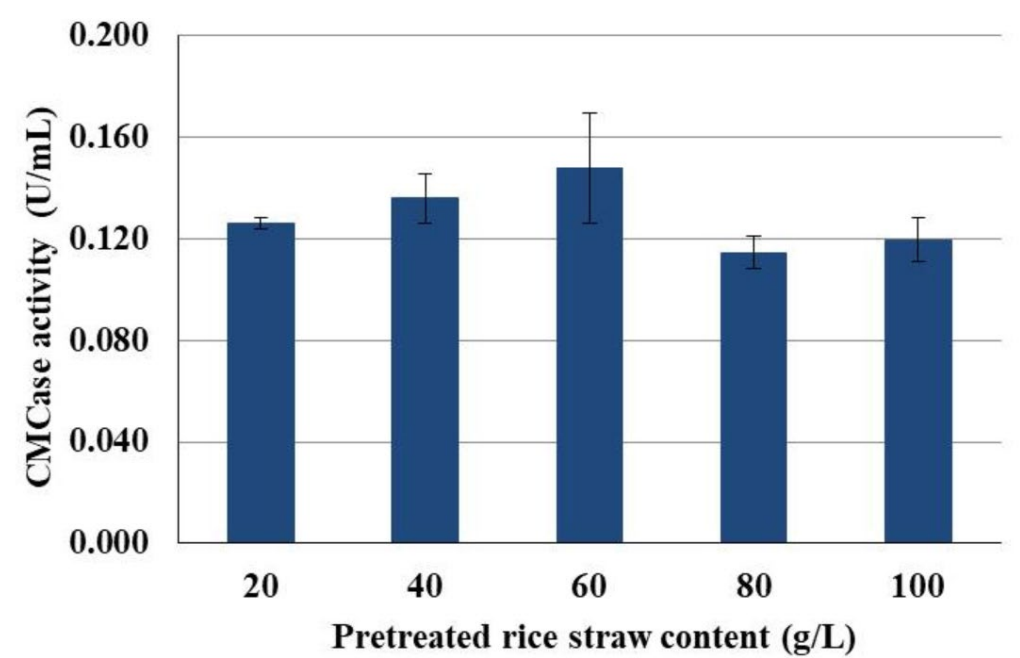

Fig. 4. The $C M C a s e$ activity of isolate $\mathrm{CP} 1$ when using various content of pretreated rice straw as a substrate for semi-solid-state fermentation and incubating at $40^{\circ} \mathrm{C}$ for $5 \mathrm{~d}$. 
were used to isolate endoglucanases producing microorganisms and the result showed that all of our endoglucanases producing isolates were gram positive and filamentous in shape that are characteristics of actinomycetes, In agreement with our study, actinomyces are well known to be components of the microflora of composts. ${ }^{34}$ Most of actinomyces capable of producing cellulolytic enzyme belonging to the genus Streptomyces, such as S. albogriseolus, ${ }^{35}$ S. flavogriseus, ${ }^{36} \mathrm{~S}$. albaduncus, ${ }^{37}$ S. cellulolyticus, ${ }^{38}$ and S. albospinus. ${ }^{39}$ In our study, $S$. thermocoprophilus CP1 could produce endoglucanases at a $\mathrm{pH}$ range of 3.0 to 7.0. The enzyme production was drastically reduced at $\mathrm{pH}$ 6.0-7.0 and was not observed at $\mathrm{pH}$ 8.0. The initial $\mathrm{pH}$ has been reported to influence enzymes transport across the cell membrane. ${ }^{40}$ The optimal $\mathrm{pH}$ for endoglucanases production of Streptomyces spp. was varied from 5.0 to 7.0. Similar to our results, the optimal $\mathrm{pH}$ for cellulase production of Streptomyces sp. MDS was 5.0. ${ }^{41}$ In contrast, the optimal $\mathrm{pH}$ for cellulase and xylanase productions of Streptomyces sp. AMT-3, ${ }^{42}$ S. transformant T3-1 $1^{43}$ and S. drozdowiczii ${ }^{44}$ were 6.5-7.0.

Temperature is one of the key factors that significantly impacts microbial growth and enzyme production. In this study, we investigated a temperature range of $30-50^{\circ} \mathrm{C}$ for the optimal temperature for endoglucanases production by $S$. thermocoprophilus $\mathrm{CP} 1$. This strain gave the highest $\mathrm{HC}$ value of $2.49 \pm 0.01$ at $45^{\circ} \mathrm{C}$ (Fig. 3). Several studies have shown that optimal temperatures for cellulase production of $S$. drozdowiczii, ${ }^{44}$ Streptomyces T3-143 and Streptomyces sp. SLBA- $08^{8}$ were more than $45^{\circ} \mathrm{C}$. However, some Streptomyces strains such as S. albidofavus SAMRCUFH5 $5^{45}$ and Streptomyces sp. MDS ${ }^{41}$ optimally produced cellulases at lower temperature $\left(40^{\circ} \mathrm{C}\right)$. The ability to grow and produce cellulolytic enzymes at high temperature $\left(35-50^{\circ} \mathrm{C}\right)$ in acidic condition makes $S$. thermocoprophilus $\mathrm{CP} 1$ suitable for co-cultivation with other thermotolerant yeast such as $K$. marxianus and $S$. cerevisiae (thermotolerant strains) to produce some valuable products in simultaneous saccharification and fermentation (SSF).

A suitable pretreatment method is a key in breaking down the recalcitrant lignin structure leading to the accessibility of cellulose towards hydrolytic enzymes for its conversion into monosaccharides. ${ }^{15}$ There are various pretreatment processes applied for lignocellulosic biomass. The choice of pretreatment methods relies on economic factor, type of lignocellulosic feedstock, and environmental impacts. In present study, a rice straw was milled and followed by alkali pretreatment carried out at high temperatures $\left(121^{\circ} \mathrm{C}\right)$ for $15 \mathrm{~min}$. Milling can increase the specific surface area for enzymatic hydrolysis and degree of

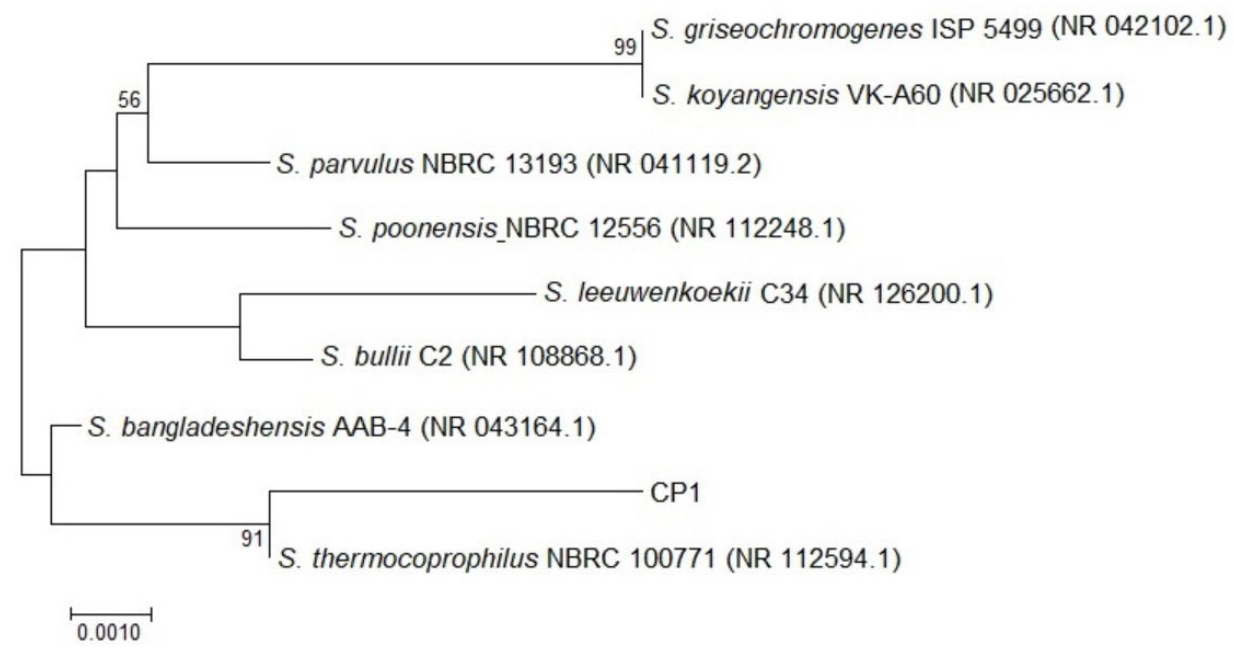

Fig. 5. Neighbor-joining tree of the isolate CP1 and other Streptomyces species. Values on nodes represent percentage bootstraps out of 1000 bootstrap samples; values less than $50 \%$ are not shown. Scale bar represents the number of mutations per sequence position. 
polymerization, but at the same time can reduce cellulose crystallinity. Alkali application is able to alter the structure of lignin by degrading ester and glycosidic side chains, cellulose swelling, and partial cellulose recrystallization. However, only alkali pretreatment would not be enough to remove hemicellulose. Therefore, to enhance cellulase productivity by increasing cellulose accessibility to cellulolytic enzymes, other pretreatment methods should be investigated. Ionic liquid pretreatment is a novel and emerging pretreatment technologies. Recently, the application of ionic liquid (IL) for lignocellulose pretreatment has attracted considerable attention. These compounds have been exploited extensively due to their green properties, high thermal stabilities and negligible vapor pressures preventing the release of toxic gases. Pretreatment of rice straw with cholinium amino acids ionic liquids ([Ch][AA] ILs), a novel type of bio-ILs, resulted in the improvement of the initial saccharification rates of rice straw residues and polysaccharide digestion ${ }^{45}$.

Submerged and solid state fermentation has been used for cellulases production. ${ }^{40}$ Generally, the production of cellulases by microorganisms has been reported to utilize the submerged fermentation..$^{20-25,47,48}$ However, for cellulases production, the use of lignocellulosic biomass along with the application of cost effective fermentation strategies such as solidstate fermentation has been suggested. ${ }^{49}$ The solid-state fermentation usually used for fungi cultivation ${ }^{50-52}$ but not for Streptomyces species. However, we found that $S$. thermocoprophilus CP1 could grow and produce cellulase using semi-solid state fermentation. Therefore, our result would be useful for further investigation on using semi-solid state fermentation for cellulases production from others lignocellulosic biomass by Streptomyces spp.

To make concept of biorefineries economically feasible, genetic engineering techniques have been used recently to improve the enzymatic expression of microorganisms. ${ }^{15}$ Unlike Escherichia coli, Streptromyces spp. have not been a popular microorganisms for metabolic engineering because they are not well-characterized. However, during the last decade, metabolic engineering strategies have been applied to more microorganism species other than E. coli. ${ }^{53}$ CelStrep, a 379-amino-acid endoglucanase encoded by celstrep gene, was identified in Streptomyces sp. strain G12 and classified as a family 12 glycoside hydrolase. By using recombinant technology, the recombinant CelStrep was successfully produced by $E$. coli. ${ }^{54}$ Since molecular genetic tools are available for Streptomyces spp., cellulase gene cloning and sequencing could be further carried out in our strain.

Streptomyces is considered to be a very large genus consisting of more than 500 species with the number increasing every year. Among closely related Streptomyces species, their $16 \mathrm{~S}$ rRNA gene sequences are very similar. This sometimes can cause ambiguity in molecular identification of Streptomyces spp. For example, the BLASTN analysis showed that 16S rRNA gene sequence of the isolate GMKU 937 was found to be 99\% identical to that of Streptomyces coelicoflavus NBRC 15399 but the phylogenetic analysis demonstrated that Streptomyces diastaticus NRRL B-1773 15399 was the closest species of the isolate GMKU $937 .{ }^{55}$ Sometimes results from the BLASTN analysis and phylogenetic analysis were in agreement but the bootstrap supports in phylogenetic trees were very low (less than $50 \%$ ). ${ }^{56}$ Fortunately, those problems were not found in this study. The isolate CP1 was concordantly identify as Streptomyces thermocoprophilus by both BlastN analysis and phylogenetic analysis with high percentage bootstrap support.

\section{CONCLUSIONS AND FUTURE RESEARCH PERSPECTIVES}

S. thermocoprophilus CP1 isolated from the compost was shown to produce endoglucanases using rice straw as a substrate. This finding may be beneficial not only for industries but also environments. The endoglucanases produced by $S$. thermocoprophilus CP1 may convert environmental wastes such as rice straw and other cellulosic biomass to produce sugars for various industries including bioethanol and other bioactive natural products production. Future studies should also consider investigating the sustainability features of the developed platform using advanced sustainability assessment tools such as LCA, exergy and their combination as mention in several articles. ${ }^{57-58}$ In addition, enzyme 
characterization, productions of exoglucanase and beta-glucosiadse, improving enzyme productivity by using genetic tools should be further studied in $\mathrm{S}$. thermocoprophilus CP1.

\section{ACKNOWLEDGMENTS}

The authors gratefully acknowledge the support of the present work through the Faculty of Science, Ubon Ratchathani University, Ubon Ratchathani, Thailand.

\section{CONFLICT OF INTEREST}

The authors declare that there is no conflict of interest.

\section{AUTHORS' CONTRIBUTION}

All authors listed have made a substantial, direct and intellectual contribution to the work, and approved it for publication.

\section{FUNDING}

This study was funded by Research Professional Development Project under the Science Achievement Scholarship of Thailand (SAST).

\section{DATA AVAILABILITY}

All datasets generated or analyzed during this study are included in the manuscript.

\section{ETHICS STATEMENT}

This article does not contain any studies with human participants or animals performed by any of the authors.

\section{REFERENCES}

1. Potprommanee $L$, Wang $X-Q$, Han $Y-J$, et al. Characterization of a thermophilic cellulase from Geobacillus sp. HTA426, an efficient cellulase-producer on alkali pretreated of lignocellulosic biomass. PLoS One. 2017;12(4):e0175004. doi: 10.1371/journal. pone. 0175004

2. Maki M, Leung KT, Qin W. The prospects of cellulaseproducing bacteria for the bioconversion of lignocellulosic biomass. Int J Biol Sci. 2009;5(5):500516. doi: 10.7150/ijbs.5.500

3. Quiroz-Castaneda RE, Folch-Mallol JL. Hydrolysis of biomass mediated by cellulases for the production of sugars, sustainable degradation of lignocellulosic biomass. In Chandel AK and da Silva SS (eds.), Techniques, applications and commercialization. IntechOpen, London. 2013. doi: 10.5772/53719

4. Horn SJ, Vaaje-Kolstad G, Westereng B, Eijsink
VGH. Novel enzymes for the degradation of cellulose. Biotechnol Biofuels. 2012;5(45):1-12. doi: 10.1186/1754-6834-5-45

5. Kostylev M, Wilson D. Synergistic interactions in cellulose hydrolysis. Biofuels. 2012;3(1):61-70. doi: 10.4155/bfs.11.150

6. Gupta P, Samant K, Sahu A. Isolation of cellulosedegrading bacteria and determination of their cellulolytic potential. Int J Microbiol. 2012;2012:578925. doi: 10.1155/2012/578925

7. Sukumaran RK, Singhania RR, Pandey A. Microbial cellulases production, applications and challenges. J Sci Ind Res. 2005;64(11):832-844.

8. Macedo EP, Cerqueira CLO, Souza DAJ, et al. Production of cellulose degrading enzyme on sisal and other agro-industrial residues using a new Brazilian actinobacteria strain Streptomyces sp. SLBA-08. Braz J Chem Eng. 2013;30(4):729-735. doi: 10.1590/S010466322013000400005

9. Sadhu S, Maiti TK. Cellulase production by bacteria: A Review. Br Microbiol Res J. 2013;3(3):235-258. doi: 10.9734/BMRJ/2013/2367

10. Saini A, Aggarwal NK, Sharma A, Yadav A. Actinomycetes: a source of lignocellulolytic enzymes. Enzyme Res. 2015;2015:279381. doi: 10.1155/2015/279381

11. Bonechi $C$, Consumi $M$, Donati $A$, et al. Biomass: An overview. In Dalena F, Basile A, Rossi C (eds.), Bioenergy systems for the future. Bioenergy Systems for the Fuure. 2017:3-42. doi: 10.1016/B978-0-08101031-0.00001-6

12. Branco RHR, Serafim LS, Xavier AMRB. Second generation bioethanol production: on the use of pulp and paper industry wastes as feedstock. Fermentation. 2019;5(1):4. doi: 10.3390/fermentation5010004

13. Kim J-W, Kim K-S, Lee J-K, et al. Two-stage pretreatment of rice straw using aqueous ammonia and dilute acid. Bioresour Technol. 2011;102(19):8992-8999. doi: 10.1016/j.biortech.2011.06.068

14. McMillan JD. Pretreatment of lignocellulosic biomass. In Himmel ME, Baker JO, Overend RP (eds), Enzymatic conversion of biomass for fuels production. American Chemical Society, Washington, DC. 1994:292-324. doi: 10.1021/bk-1994-0566.ch015

15. Lugani $Y$, Rai R, Prabhu AA, et al. Recent advances in bioethanol production from lignocelluloses: a comprehensive review with a focus on enzyme engineering and designer biocatalysts. Biofuel Res J. 2020;28:1267-1295. doi: 10.18331/BRJ2020.7.4.5

16. Kophimai $Y$, Cheenacharoen S, Simister R, et al. Straw digestibility of Thai rice accessions. Agr Nat Resour. 2020;54(6):617-622. doi: 10.34044/j. anres.2020.54.6.07

17. Lu P, Hsieh Y-L. Preparation and characterization of cellulose nanocrystals from rice straw. Carbohydr Polym. 2012;87(1):564-573. doi: 10.1016/j. carbpol.2011.08.022

18. Tursi A. A review on biomass: importance, chemistry, classification, and conversion. Biofuel Res $J$. 2019;22:962-979. doi: 10.18331/BRJ2019.6.2.3

19. Kogo T, Yoshida Y, Koganei K, et al. Production of rice straw hydrolysis enzymes by the fungi Trichoderma reesei and Humicola insolens using rice straw as a 
carbon source. Bioresour Technol. 2017;233:67-73. doi: 10.1016/j.biortech.2017.01.075

20. Budihal SR, Agsar D, Patil SR. Enhanced production and application of acidothermophilic Streptomyces cellulase. Bioresour Technol. 2016;200:706-712. doi: 10.1016/j.biortech.2015.10.098

21. Haroune LM, Zaidi F, Adrar SM. et al. Bioconversion of olive pomace by submerged cultivation of Streptomyces sp. S1M3I. Proc Natl Acad Sci. 2018;88(4):1425-1433. doi: 10.1007/s40011-017-0880-x

22. Sakpetch P, H-Kittikun A, Chandumoa A. Isolation and screening of potential lignocellulolytic microorganisms from rubber bark and other agricultural residues. Walailak J Sci \& Tech. 2017;14(12):953-967.

23. Soeka YS, Suharna N, Triana E, Yulinery T. Characterization of cellulase enzyme produced by two selected strains of Streptomyces macrosporeus isolated from soil in Indonesia. Makara J Sci. 2019;23(2):65-71. doi: $10.7454 / \mathrm{mss} . v 23 \mathrm{i} 2.11043$

24. Sinjaroonsak S, Chaiyaso T, H Kittikun A. Optimization of cellulase and xylanase productions by Streptomyces thermocoprophilus TC13W using low cost pretreated oil palm empty fruit bunch. Waste Biomass Valor. 2020;11:3925-3936. doi: 10.1007/s12649-01900720-y

25. Nguyen BL, Hoang ATP. Screening of cellulolytic Actinomycetes for decomposition of agricultural waste. Chem Eng Trans. 2020;78:283-288.

26. Mihajlovski K, Buntić A, Milić M, Rajilić-Stojanović $M$, Dimitrijević-Branković $S$. From agricultural waste to biofuel: enzymatic potential of a bacterial isolate Streptomyces fulvissimus CKS7 for bioethanol production. Waste Biomass Valor. 2021;12:165-174. doi: 10.1007/s12649-020-00960-3

27. Wen-Jing L, Hong-Tao W, Shi-Jian Y, Zhi-Chao W, Yong-Feng $\mathrm{N}$. Isolation and characterization of mesophilic cellulose-degrading bacteria from flower stalks-vegetable waste co-composting system. J Gen Appl Microbiol. 2005;51(6):353-360. doi: 10.2323/ jgam.51.353

28. Ghose TK. Measurement of cellulase activities. Pure and App Chem. 1987;59(2):257-268. doi: 10.1351/ pac198759020257

29. Miller GL. Use of dinitrosalicylic acid reagent for determination of reducing sugar. Anal Chem. 1959;31(3):426-428. doi: 10.1021/ac60147a030

30. Amore A, Pepe O, Ventorino V, Birolo L, Giangrande C, Faraco V. Industrial waste based compost as a source of novel cellulolytic strains and enzymes. FEMS Microbiol. 2013;339(2):93-101. doi: 10.1111/1574-6968.12057

31. Ventorino V, Parillo R, Testa A, Aliberti A, Pepe O. Chestnut Biomass Biodegradation for Sustainable agriculture. Bioresources. 2013;8(3):4647-4658. doi: 10.15376/biores.8.3.4647-4658

32. Ilmberger N, Gullert S, Dannenberg J, et al. A comparative metagenome survey of the fecal microbiota of a breast- and a plant-fed Asian elephant reveals an unexpectedly high diversity of glycoside hydrolase family enzymes. PLOS One. 2014;9(9):e106707. doi: 10.1371/journal. pone. 0106707

33. Lopez-Lopez O, Cerdan ME, Gonzalez-Siso MI. Hot spring metagenomics. Life. 2013;3(2):308-320. doi: 10.3390/life3020308

34. Abdulla HM, El-Shatoury SA. Actinomycetes in rice straw decomposition. Waste Manag. 2007;27(6):850853. doi: 10.1016/j.wasman.2006.06.006

35. Van Zyl WH. A study of the cellulases produced by three mesophilic actinomycetes grown on bagasse as substrate. Biotechnol Bioeng. 1985;27(90):1367-1373. doi: 10.1002/bit.260270914

36. McCarthy AJ. Lignocellulose-degrading actinomycetes. FEMS Microbiology Letters. 1987;3(2):145-163. doi: 10.1111/j.1574-6968.1987.tb02456.x

37. Harchand RK, Singh S. Catabolite repression of cellulase biosynthesis in Streptomyces albaduncus. J Basic Microbiol. 1994;34(6):371-378. doi: 10.1002/ jobm.3620340603

38. Li X. Streptomyces cellulolyticus sp. nov., a new cellulolytic member of the genus Streptomyces. Int J Syst Bacteriol. 1997;47(2):443-445. doi: 10.1099/00207713-47-2-443

39. Prasad P, Bedi S, Singh T. In vitro cellulose rich organic material degradation by cellulolytic Streptomyces albospinus (MTCC 8768). Malays J Microbiol. 2012;8(3):164-169. doi: 10.21161/mjm.04312

40. Goyal V, Mittal A, Bhuwal AK, Singh G, Yadav A, Aggarwal NK. Parametric optimization of cultural conditions for carboxymethyl cellulase production using pretreated rice straw by Bacillus sp. 313SI under stationary and shaking conditions. Biotechnol Res Int. 2014;2014:651839. doi: 10.1155/2014/651839

41. Saratale GD, Saratale RG, Oh SE. Production and characterization of multiple cellulolytic enzymes by isolated Streptomyces sp. MDS. Biomass Bioenergy. 2012;47:302-315. doi: 10.1016/j. biombioe.2012.09.030

42. Nascimento RP, Coelho RRR, Marques S, et al. Production and partial characterisation of xylanase from Streptomyces sp. strain AMT-3 isolated from Brazilian cerrado soil. Enzyme Microb Technol. 2002;31(4):549555. doi: 10.1016/S0141-0229(02)00150-3

43. Jang HD, Chen KS. Production and characterization of thermostable cellulases from Streptomyces transformant T3-1. World J Microbiol Biotechnol. 2003;19:263-268. doi: 10.1023/A:1023641806194

44. Grigorevski-Lima AL, Nascimento RP, Bon SEP, Coelhoa RRR. Streptomyces drozdowiczii cellulase production using agro-industrial by-products and its potential use in the detergent and textile industries. Enzyme Microb Technol. 2005;37(2):272-277. doi: 10.1016/j. enzmictec.2005.03.016

45. Hou X-D, Smith TJ, Li N, Zong M-H. Novel renewable ionic liquids as highly effective solvents for pretreatment of rice straw biomass by selective removal of lignin. Biotechnol Bioeng. 2012;109(10):2484-2493. doi: 10.1002/bit.24522

46. Cunha FM, Esperanca MN, Zangirolami TC, Badino AC, Farinas CS. Sequential solid-state and submerged cultivation of Aspergillus niger on sugarcane bagasse for the production of cellulase. Bioresour Technol. 2012;112:270-274. doi: 10.1016/j. biortech.2012.02.082

47. Assareh R, Zahiri HS, Noghabi KA, Aminzadeh S, khaniki 
GB. Characterization of newly isolated Geobacillus sp. $\mathrm{T} 1$, the efficient cellulase-producer on untreated barley and wheat straws. Bioresour Technol. 2012;120:99105. doi: 10.1016/j.biortech.2012.06.027

48. Rastogi G, Bhalla A, Adhikari A, et al. Characterization of thermostable cellulases produced by Bacillus and Geobacillus strains. Bioresour Technol. 2010;101(22):8798-8806. doi: $10.1016 / \mathrm{j}$. biortech.2010.06.001

49. Sukumaran RK, Singhania RR, Mathew GM, Pnadey A. Cellulase production using biomass feedstock and its application in lignocellulose saccharification for bioethanol production. Renew Energy. 2009;34(2):421424. doi: 10.1016/j.renene.2008.05.008

50. Takano M, Hoshino K. Bioethanol production from rice straw by simultaneous saccharification and fermentation with statistical optimized cellulase cocktail and fermenting fungus. Bioresour Bioprocess. 2018;5:16. doi: 10.1186/s40643-018-0203-y

51. Maftukhah S, Abdullah A. Cellulase Enzyme Production From Rice Straw Using Solid State Fermentation and Fungi Aspergillus niger ITBCC L74. MATEC Web Conf. 2018;156:01010. doi: 10.1051/ matecconf/201815601010

52. Sarkar N, Aikat K. Cellulase and xylanase production from rice straw by a locally isolated fungus Aspergillus fumigatus NITDGPKA3 under solid state fermentation - statistical optimization by response surface methodology. J Technol Innov Renew Energy. 2012;1(1):54-62. doi: 10.6000/19296002.2012.01.01.7

53. Bekker V, Dodd A, Brady D, Rumbold K. Tools for metabolic engineering in Streptomyces. Bioengineered. 2014;5(5):293-299. doi: 10.4161/bioe.29935

54. Amore A, Pepe O, Ventorino V, Birolo L, Giangrande $C$, Faraco V. Cloning and recombinant expression of a cellulase from the cellulolytic strain Streptomyces sp. G12 isolated from compost. Microb Cell Fact. 2012;11:164. doi: 10.1186/1475-2859-11-164

55. Bunyoo C, Duangmal K, Nuntagij A, Thamchaipenet A. Characterisation of endophytic actinomycetes isolated from wattle trees (Acacia auriculiformis A. Cunn. ex Benth.) in Thailand. Thai J Gene. 2009;2(2):155-163. doi: 10.14456/tjg.2009.1

56. Chaves JV, Ojeda CPO, Silva DIR, de Lima Procopio RE. Identification and Phylogeny of Streptomyces Based on Gene Sequences. Res J Microbiol. 2018;13(1):13-20. doi: 10.3923/jm.2018.13.20

57. Rosen MA. Environmental sustainability tools in the biofuel industry. Biofuel Res J. 2018;17:751-752. doi: 10.18331/BRJ2018.5.1.2

58. Soltanian S, Aghbashlo M, Almasi F, et al. A critical review of the effects of pretreatment methods on the exergetic aspects of lignocellulosic biofuels. Energy Convers Manag. 2020;212:112792. doi: 10.1016/j. enconman.2020.112792 